University of Louisville

ThinkIR: The University of Louisville's Institutional Repository

Electronic Theses and Dissertations

$12-2009$

\title{
Analysis of patient throughput time at Kosair Children's Hospital emergency room.
}

Elizabeth Gentry

University of Louisville

Follow this and additional works at: https://ir.library.louisville.edu/etd

\section{Recommended Citation}

Gentry, Elizabeth, "Analysis of patient throughput time at Kosair Children's Hospital emergency room." (2009). Electronic Theses and Dissertations. Paper 484.

https://doi.org/10.18297/etd/484

This Master's Thesis is brought to you for free and open access by ThinkIR: The University of Louisville's Institutional Repository. It has been accepted for inclusion in Electronic Theses and Dissertations by an authorized administrator of ThinkIR: The University of Louisville's Institutional Repository. This title appears here courtesy of the author, who has retained all other copyrights. For more information, please contact thinkir@louisville.edu. 


\title{
ANALYSIS OF PATIENT THROUGHPUT TIME AT KOSAIR CHILDREN'S
}

HOSPITAL EMERGENCY ROOM

\author{
By \\ Elizabeth Gentry \\ B.S., University of Louisville, 2008

\begin{abstract}
A Thesis
Submitted to the Faculty of the

University of Louisville

J.B. Speed School of Engineering

in Partial Fulfillment of the Requirements

for the Professional Degree
\end{abstract}

MASTER OF ENGINEERING

Department of Industrial Engineering

December 2009 



\title{
ANALYSIS OF PATIENT THROUGHPUT TIME AT KOSAIR CHILDREN'S HOSPITAL EMERGENCY ROOM
}

\author{
Submitted by: \\ Elizabeth Gentry \\ A Thesis Approved On \\ (Date)
}

by the Following Reading and Examination Committee:

Dr. Gail DePuy, Thesis Director

Dr. Gerald Evans

Dr. James Lewis 


\section{ACKNOWLEDGEMENT}

I would first like to thank my grandpa, Austin Wise (1924-2009), for teaching me valuable lessons and telling me to strive for my best in everything I do. He was an excellent role model to me and I will never forget what he taught me.

I would like to thank Kosair Children's Hospital for allowing me to conduct time studies in their emergency room. I would also like to thank Carla Sanders, Scott Stanton, and Liz Younger of Kosair Children's Hospital for taking time to explain to me the layout and processes of the emergency room.

I would like to thank Dr. Gerald Evans for taking time to be on my thesis committee and helping me pursue my academic goals. I would also like to thank Dr. Jim Lewis for not only being on my thesis committee, but also guiding me in discovering my love for leadership and teaching. Last but definitely not least; I would like to thank my

thesis director, Dr. Gail DePuy for being there every step of the way and guiding me to reach my academic potential. 


\begin{abstract}
Kosair Children's Hospital Emergency Department in Louisville, KY has been reporting low patient satisfaction, which could result in a decrease in revenue and patients for the hospital. Patient throughput times in Kosair's emergency room have a significant effect on patient satisfaction. This thesis will evaluate the emergency room at Kosair Children's Hospital through a time study. The time study analyzes value added time and non-value added time in the emergency room. The majority of the patient throughput time is non-value added time and needs to be minimized. Solutions to minimize the nonvalue added time and future studies to continuously improve the emergency room have been reported to administrators at Kosair Children's Hospital for future implementation.
\end{abstract}




\section{TABLE OF CONTENTS}

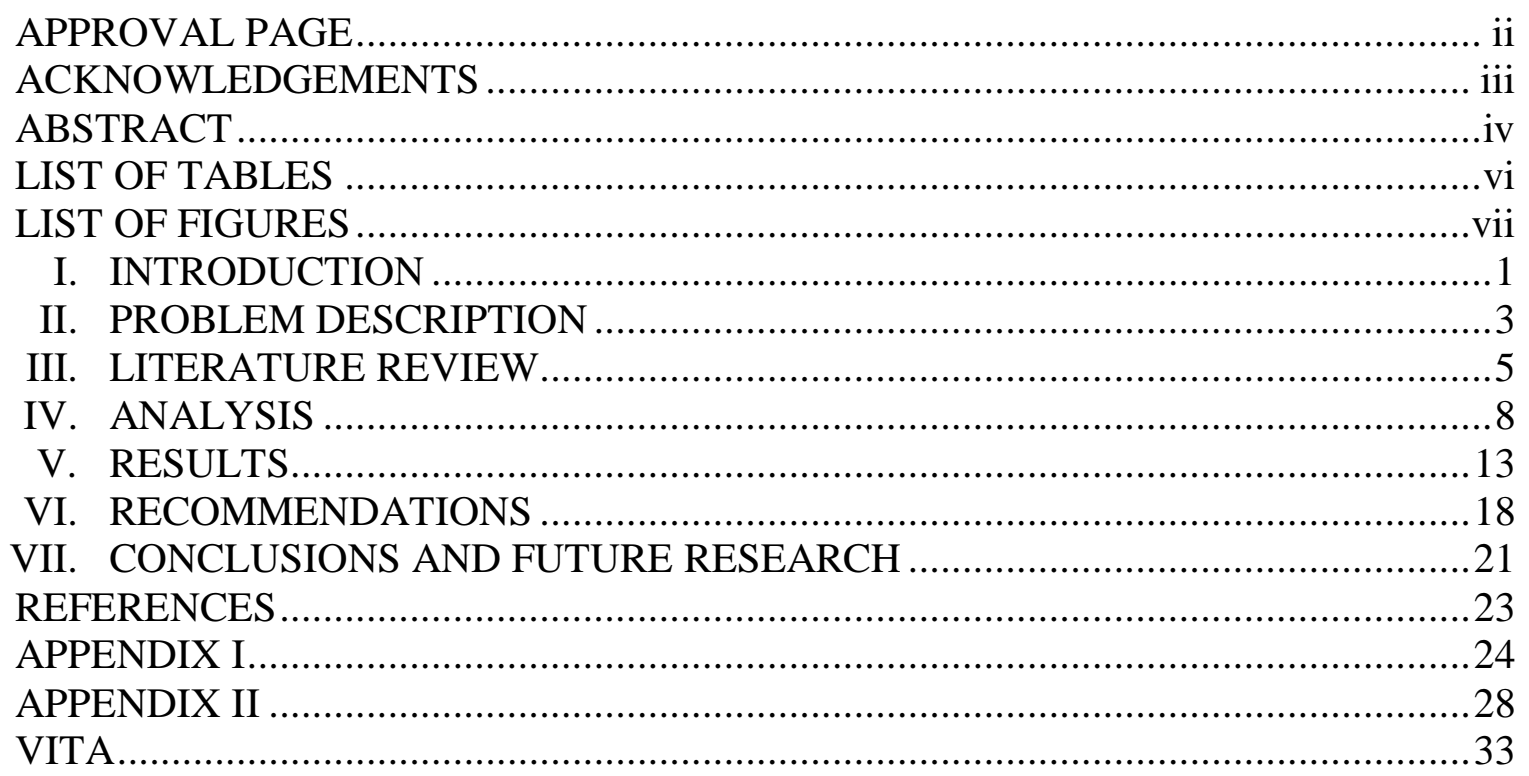




\section{LIST OF TABLES}

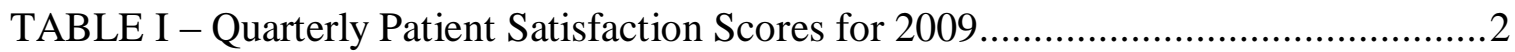

TABLE II -Patient Severity Level Classification ........................................................... 10

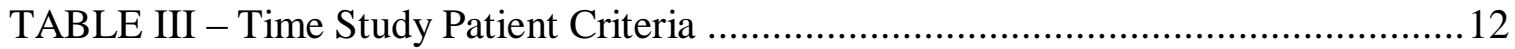

TABLE IV - Total Patient Throughput Time …………...........................................13

TABLE V - Value Added Time: Critical Steps............................................................15

TABLE VI - Value Added Time: Nurse Steps...........................................................16

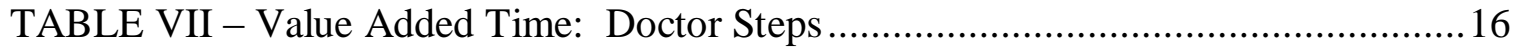

TABLE VIII - Non-Value Added Time: Events ........................................................19

TABLE IX - Non-Value Added Time: Conflicts .....................................................20

TABLE X - Individual Patient Wait Time ……………...........................................24

TABLE XI - Individual Patient Time with the Doctor ................................................2.

TABLE XII - Individual Patient Time with the Nurse ……........................................2.

TABLE XIII - Individual Patient Time in Ancillary Services ......................................2.

TABLE XIV - Individual Patient Total Throughput Time ….......................................27 


\section{LIST OF FIGURES}

FIGURE 1 - Map of Ground Floor of Kosair Children's Hospital....................................

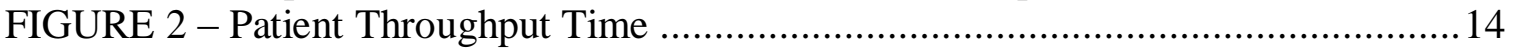

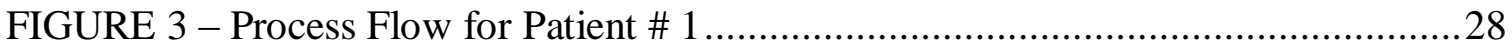

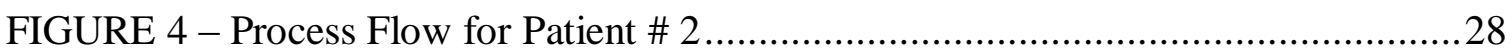

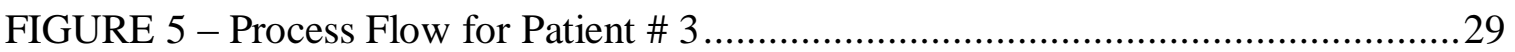

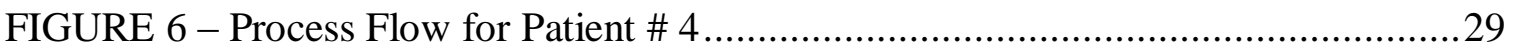

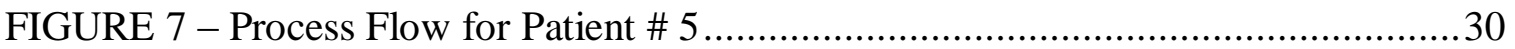

FIGURE 8 - Process Flow for Patient \# 6 .............................................................

FIGURE 9 - Process Flow for Patient \# 7 ............................................................ 31

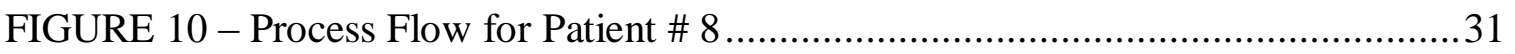

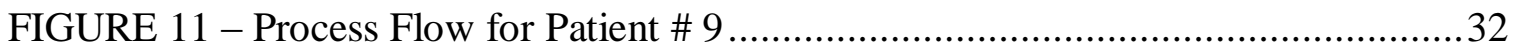

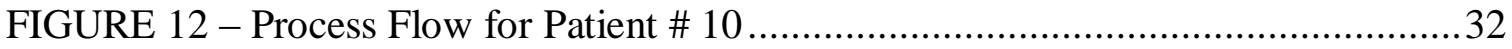




\section{INTRODUCTION}

The National Center for Health Statistics (2009) reported that 21.3 percent of all children under age 18 visited an emergency room in 2006 . With this many patients a year, a patient's time in the emergency room can be long. Industrial engineers can help improve many aspects of healthcare including improving patient throughput time. The total time spent waiting in the emergency room has much to do with patient satisfaction. Short patient throughput times directly relates to high patient satisfaction. Industrial engineers can improve patient satisfaction by finding ways to reduce the patient throughput time. Time studies are a good way to determine how much time of a patient's visit is not adding value and how to eliminate the non-value added time.

The Emergency Room at Kosair Children's Hospital in Louisville, Kentucky needs an improvement in patient satisfaction. The quarterly patient satisfaction scores of the emergency room at Kosair Children's Hospital for 2009 are shown in Table I. In Table I, the actual scores and the targeted scores are reported for each quarter in a scale of 1-100. The targets scores are what Kosair administration aims for and believes that the score is attainable for that quarter. Kosair, however, failed to reach these targeted scores and also did not meet the National Average for patient satisfaction scores. 


\section{TABLE I}

QUARTERLY PATIENT SATISFACTION SCORES FOR 2009

\begin{tabular}{|c|c|c|}
\hline Year 2009 & Patient Satisfaction Score & Patient Satisfaction Target \\
\hline $1^{\text {st }}$ Quarter & 78.1 & 81.1 \\
\hline $2^{\text {nd }}$ Quarter & 79.8 & 81.5 \\
\hline $3^{\text {rd }}$ Quarter & 79.9 & 82.1 \\
\hline $4^{\text {th }}$ Quarter & 77.5 & 82.6 \\
\hline
\end{tabular}

The target patient satisfaction score was not reached in any of the four quarters of 2009. Low patient satisfaction scores affects hospital revenue negatively. Patients in Louisville have an increasing number of hospitals from which to choose. The low patient satisfaction scores of the emergency room may cause patients to choose other hospitals in the area. The goal of this study is to improve patient satisfaction in the emergency room at Kosair Children's Hospital by finding solutions to decrease patient throughput time.

The remainder of this thesis is organized as follows. Chapter II will address the problem description more thoroughly. Chapter III summarizes the current literature for this research topic. Chapter IV addresses the analysis of the research study. Chapter V reports the results of the research study. Chapter VI presents recommendations for improvement. Chapter VII concludes with addressing important findings of the research study and future research. 


\section{PROBLEM DESCRIPTION}

In the emergency room of Kosair Children's Hospital, the critical steps, that need to be conducted while the patient is in the emergency room, do not usually require much time and need to happen in order for the patient to be successfully treated. The problem is the time in between each critical step. This non-value added time needs to be reduced to satisfy patients, their parents/guardians, as well as employees in the emergency room at Kosair Children's Hospital.

Patient throughput time includes value added time plus non-value added time. Value added time includes all critical steps or steps that need to happen for the patient to exit the emergency room such as when the doctor visits the patient. The exit of the emergency room includes the patient leaving the hospital or the patient being admitted to the hospital. Non-value added time includes all steps that are not needed and all the waiting time in between each step such as PCAs cannot find a wheelchair to transport patient to get an X-Ray or Catscan. Kosair Children's Hospital needs their patient throughput times decreased. All the critical steps, which are value added time, cannot be eliminated. However, non-value added time needs to be eliminated as much as possible.

Comparing hospitals to manufacturing facilities, hospitals are similar to a job shop manufacturing facility. In a job shop, there are different types of products being manufactured, just like in an emergency room where patients have many different types of symptoms. The difficulty in job shops and hospitals is that there is high variability in the products or patients and their times in the facility will be different for each type of product or patient. In a job shop, for each product being manufactured, it will have a 
different process flow through the workstations; however the different products may visit many of the same workstations. Hospital patients will have some of critical steps in common as well, but not usually all the steps and the order of the steps is probably not going to be the exact same order. The solution to improving patient throughput time with this variability is to eliminate as much non-value added time as possible and to put the value added steps in the best order that saves time to reduce patient throughput time in the emergency room at Kosair Children's Hospital. 


\section{LITERATURE REVIEW}

Improving the patient satisfaction at the Kosair Children's Hospital emergency room by reducing throughput time is the primary goal of this study. A review of the current literature provides insight into how to accomplish this goal.

Johnson, Roberts, Shanmugam, \& Zinkgraf (2004) report that the increase in healthcare and insurance costs have directly affected the amount of emergency room visits. Kosair Children's Hospital works with patients with and without insurance to make sure no child is turned away. Many patients go to the emergency room at Kosair Children's Hospital for ailments that can be treated by a primary care doctor because the patient cannot afford the costs of the primary care doctor. Gonzalez, Gonzalez, \& Rios (1997) pointed out that the most crowded time of the emergency department is from 6:00 pm to 9:00 pm on weekdays, along with weekends and holidays. Also, for a children's hospital, many parents will have time restrictions during the day and will have to take the child in the evening. Most primary care doctors are not available in the evenings. Therefore, the time studies in this thesis were focused during the evenings because this was the most crowded time and therefore directly resulted in the longest patient throughput time.

The main ancillary Services at Kosair Children's Hospital include laboratory services, radiology services, and respiratory treatments. DeGennaro, Gandhi, Kushner, Nagarkar, Rivero, \& Srihari (2004) and Johnson et al. (2004) report that a main factor in high patient throughput time is waiting on laboratory and radiology test results. This wait time decreases patient satisfaction and hospital revenue. Lin \& Paul (2007) pointed out 
that total ancillary service time was a bottleneck. The non-value added time of waiting for ancillary services or waiting for the results needs to be decreased. DeGennaro et al. (2004) suggested cross training nurses to do some of the ancillary services. Laboratory services, radiology services, and respiratory treatments are analyzed in the time study included in this thesis.

Malakooti (2004) found that grouping patients together with similar ailments improved patient throughput time. The group of similar types of patients would then take a similar process path. The paths were mapped out and created to have the groups have an efficient flow through the emergency room. This method cut back on waiting time for the patient by making sure groups did not go to a process such as getting an X-Ray at the same time. Burdick, Cochran, Kisiel, \& Modena (2007) suggested grouping patients together by severity level, instead of grouping patients together by similar ailment.

Not surprisingly, Lin \& Paul (2007) reports that the length of stay of a patient in an emergency room directly relates to patient satisfaction and this will affect hospital revenue. Burdick et al. (2007) found that making the process flow more efficient has decreased the number of patients who leave without being seen. Toward this end, Lin \& Paul (2007) created flow charts to help target processes that needed improvement and found out a major bottleneck was ancillary service time.

Gonzalez et al. (2007) found by flow charts that negative factors that affected an emergency room process were: unclear job descriptions, waiting on doctors, not enough nurses and equipment, patients cannot be admitted to the hospital because rooms are full, and patient flow problems. Targeting and improving bottleneck services will improve patient satisfaction. 
This thesis will expand on the approaches of this current literature by in depth direct observations and analysis of employees, patients, and processes in the emergency room to identify non-value added time and ways to eliminate the non-value added time. Charting the patient flow in emergency rooms, as addressed by Gonzalez et al. (2007) and Lin \& Paul (2007), was a technique employed in this thesis as well when analyzing the direct observations. As DeGennaro et al. (2004) and Johnson et al. (2004) reported that ancillary service time needed improvement; this area is a critical part of the study. However, this thesis will not just focus on improving ancillary services, it will focus on eliminating all non-value added time from the doctor's first visit with the patient's room to the patient exits the emergency room. 


\section{ANALYSIS}

This chapter will first discuss the layout and processes of the emergency room at Kosair Children's Hospital. Then, the time study procedure will be discussed in detail.

The emergency room of Kosair Children's Hospital is composed of three hallways labeled A, B, and C (see Figure 1). There are a total of 25 patient rooms in hallways $\mathrm{A}, \mathrm{B}$, and $\mathrm{C}$. In addition to the patient rooms, there are four rooms for trauma patients, four rooms for psych patients, and an area called Kids Express. Kids Express is used for patients with less severe ailments who can be treated quickly. Kids Express is only open during the evening. When Kids Express is not in operation the patients with less severe ailments are assigned to a regular ER patient room in hallway A, B, or C.

The time studies for this thesis were conducted for patients assigned to the, 8 patient rooms in hallway A. Hallway A is the busiest of the three hallways. This hallway was chosen for the time study because it is the closest hallway to the nurse's station, as well as the doctor's station. This enables the industrial engineer doing the time study to better observe the activities of the doctors and nurses when they are not in a patient room. A map of the ground floor of Kosair Children's Hospital, which includes all areas analyzed in the time study, is found in Figure 1. 


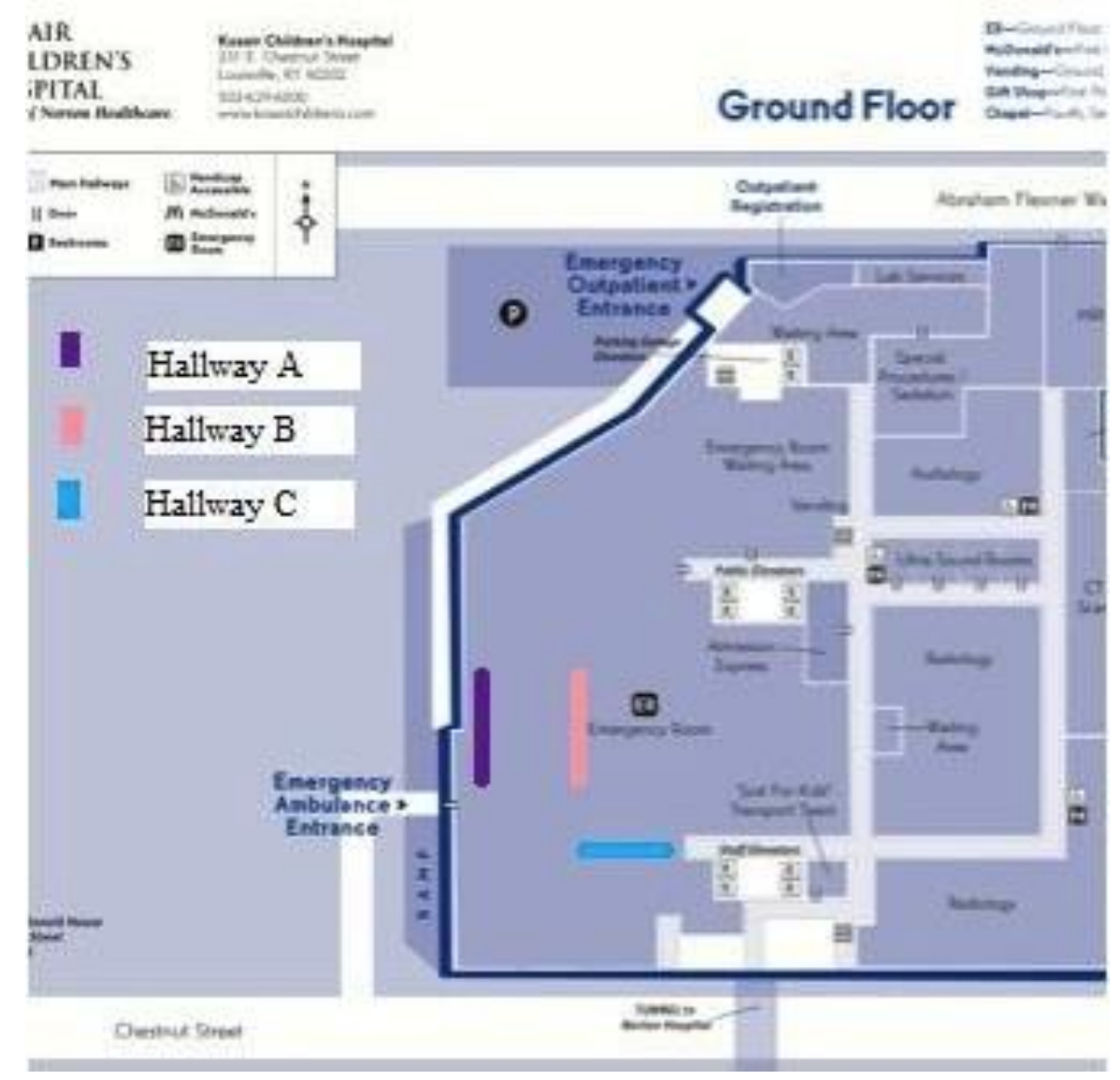

FIGURE 1 - Map of Ground Floor of Kosair Children’s Hospital

A patient can come in to the emergency room in one of two ways. The first way is by coming in by ambulance and the second way is by going to the waiting room first. If the patient comes in by ambulance, they will go straight to the emergency room. Sometimes the patient will go straight to a room, other times a nurse will check their vitals before they go to a room. Even if a patient has a yellow or orange severity level, they usually get put in a room as soon as they arrive in an ambulance, instead of waiting in the waiting room with other patients of their same severity level. The time study concentrated on patients who came into the emergency room from the waiting room. The throughput time for these patients is the longest and the majority of the patients come into 
the emergency room from the waiting room.

Before a doctor can see a patient, patients will go through the process of Triage. During the Triage process, a nurse will check the vitals and diagnose the patient with a severity level. Severity levels are divided into five different levels and each level is associated with a certain color. The color-coding system for the severity levels is shown in Table II.

\section{TABLE II}

\section{PATIENT SEVERITY LEVEL CLASSIFICATION}

\begin{tabular}{|c|c|}
\hline $\begin{array}{c}\text { Severity } \\
\text { (5 being the most severe to } 1 \\
\text { being the least severe) }\end{array}$ & Color \\
\hline 5 & Red \\
\hline 4 & Orange \\
\hline 3 & Yellow \\
\hline 2 & Blue \\
\hline 1 & Green \\
\hline
\end{tabular}

The time study for this thesis concentrated just on the severity levels of yellow and orange. These two severity levels were the most common seen in the emergency room. Green and blue patients typically have an ailment that could be easily treated, such as prescribing medicine. When Kids Express is operational, the green and blue severity patients will be assigned to Kids Express. Because of their high severity level, red level patients will typically be assigned to one of the four trauma rooms. Yellow and orange patients, are the most commonly seen, and tend to be in the emergency room at Kosair Children's Hospital for the longest amount of time according to the administration of 


\section{Kosair Children's Hospital.}

The time studies were performed during the summer of 2009 between the times of 3:30 pm and 8:00 pm on weekdays. This window of time was picked because the afternoon is when the emergency room starts getting busy. After many parents left work, they would find out that their children were sick or injured when they picked the children up from day care or school. The afternoon is also when a lot of children have practice for different sports and they will come to the hospital due to injury.

The time study started when the doctor entered the room for the first time. Therefore, the time study does not include waiting time in the waiting room or the waiting time in the room before the doctor comes in for the first visit. Originally it was thought the majority of non-value added time occurred between the time the doctor first visited the patient and the patient left the ER (i.e. the time frame covered by the time study in this thesis). However, as will be later discussed, it was discovered that much of the non-value added times occurs between the time a patient is assigned to a room and the doctor first visits. The first critical step in the patient treatment process is having the doctor come into the patient's room to conduct the initial consultation and diagnosis. After this first critical step, the order of the steps will change depending on the patient's symptoms and how busy the doctors and nurses are at that time. The final critical step, thereby marking the end of the time study for the patient, is the patient getting discharged from the emergency room, patients are discharged in one of two ways; either they are cleared to go home or they are admitted to the hospital. Patients who are released to go home have their emergency room visit culminate with a nurse going over medical instructions and paperwork with the patient. Patients who are admitted to the hospital 
will end the time study with the last step of the nurse taking the patient to their hospital room.

The time study was completed on a total of ten patients. To be included for consideration in the time study, the patient had to meet the criteria listed in Table III. Of those patients meeting the Table III criteria, patients were randomly selected for participation in this study. A patient's name, age, gender, or any other personally identifying characteristics of the patient did not factor into the decision of which patients to include in the time study and this information is not documented in the thesis to ensure the security and confidentiality of the patient's information.

TABLE III

TIME STUDY PATIENT CRITERIA

1. The patient needed to be classified in Triage as a yellow or orange patient.

2. The patient needed to be assigned to Hallway A.

3. The patient must have come into the emergency room from the waiting room.

The author conducted the time study. The author was standing in a location in Hallway A where the author could view the patient's room, along with the nurse's station and doctor's station. The patients did not know that they were being observed. The majority of the time the patient's door was closed for disease prevention, so the patient did not know what was going on in the hallway. The information was written down on paper and later transcribed to electronic form. This information included all events that affected the patient during the time of the study. 


\section{RESULTS}

The results of the time studies show that the patient throughput time from when the doctor enters the patient's room for the first time until the patient exits the emergency room averaged 154.5 minutes. Patient throughput time equals non-value added time added plus value added time. Value added time averaged 51.9 minutes and non-value added time averaged 102.6 minutes. Value added time or steps that are critical to patient care comprise only $34 \%$ of the total time, whereas non-value added time was $66 \%$ of the total patient throughput time. Table IV shows the average times of the patient throughput time. Figure 2 shows these statistics graphically. Tables X - XIV in Appendix Ishowthe patient throughput times for each of the tenpatients participating in the time study.

\section{TABLE IV}

\section{AVERAGE PATIENT THROUGHPUT TIME}

\begin{tabular}{|c|c|}
\hline \multicolumn{2}{|c|}{$\begin{array}{l}\text { Patient Throughput Time = Value Added Time }+ \text { Non-Value Added Time } \\
\text { Note: This time does not include the time in the waiting room nor the time in the patient } \\
\text { room before the doctor's first visit }\end{array}$} \\
\hline Non-Value Added Time & 102.6 minutes \\
\hline Value Added Time & 51.9 minutes \\
\hline Total Patient Throughput Time & 154.5 minutes \\
\hline
\end{tabular}




\section{Patient Throughput Time}

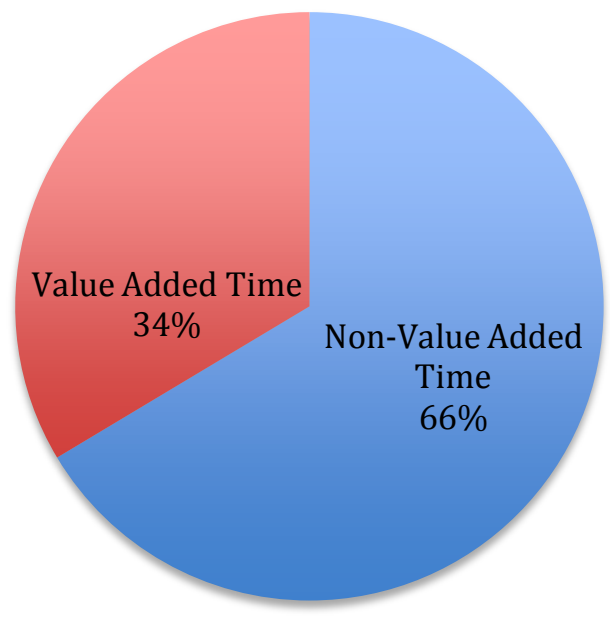

FIGURE 2 - Patient Throughput Time

Ten possible critical steps were identified over all the individual patient time studies. These ten value added steps are listed in Table V. Each patient did not need all ten critical steps. Figures $3-12$ in Appendix II shows the critical steps that were needed for each individual patient. The critical steps were value added time to the patient throughput time. Reducing the processing time of a critical step can decrease the overall throughput time. However, the most improvement to throughput time will be realized by decreasing the non-value added time. 
TABLE V

VALUE ADDED TIME: CRITICAL STEPS

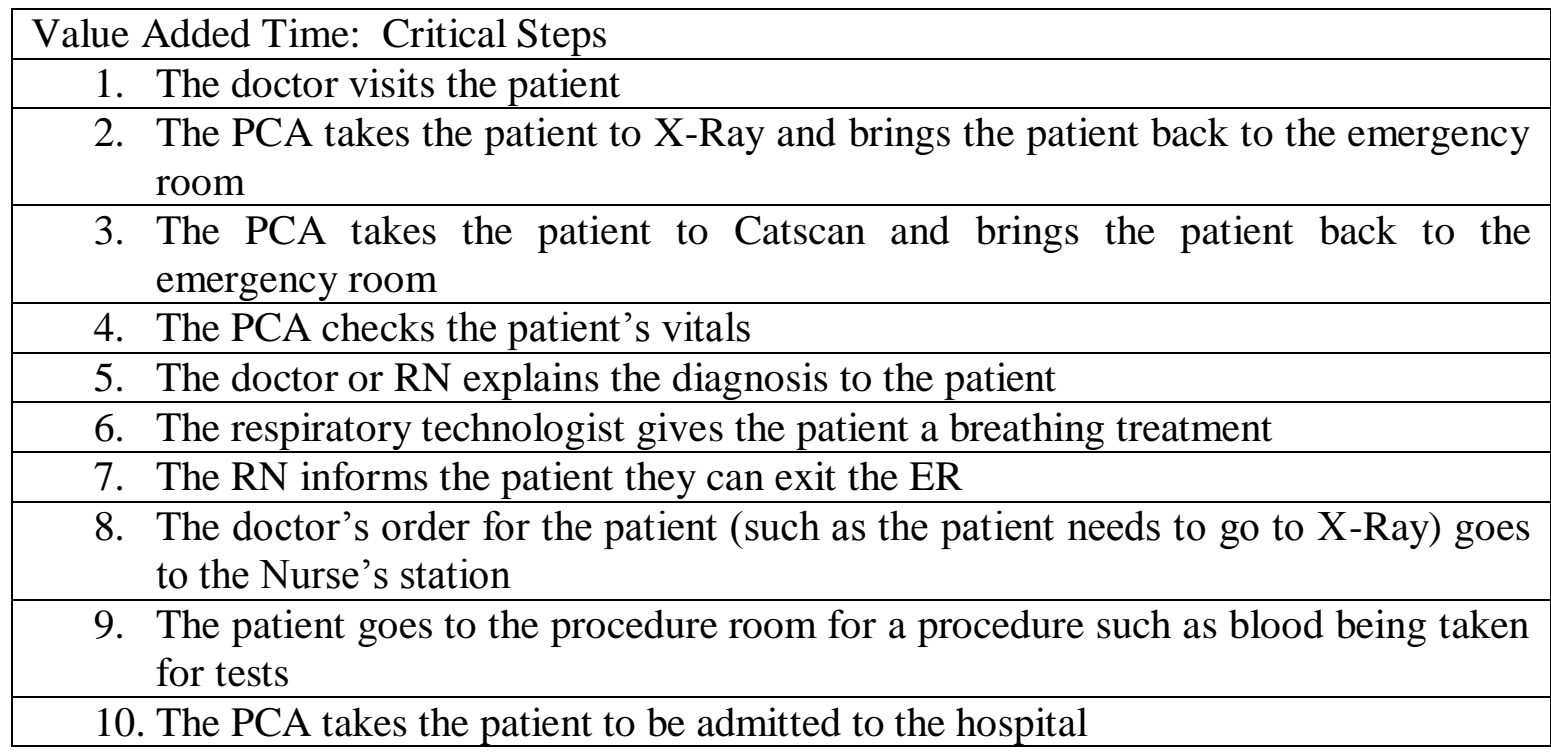

Table VI shows the average time for value added nurse steps. The time studies showed that nurses and PCAs make a visit to the patient's room, on average, 3.3 times total and the time spent in the room was 10.3 minutes, which is only $6.7 \%$ of the average total patient throughput time. The total $\mathrm{RN}$ visits averaged 1.9 times for each patient. This includes the one RN visit at the end of the time study to release the patient from the ER. 
TABLE VI

VALUE ADDED TIME: NURSE STEPS

\begin{tabular}{|l|c|}
\hline Average time RN spends in a room & 4.8 minutes \\
\hline Average time PCA spends in a room & 5.5 minutes \\
\hline Average number of times RN comes into a room & 1.9 times \\
\hline Average number of times PCA comes into a room & 1.4 times \\
\hline $\begin{array}{l}\text { Average time it takes a PCA to take a patient to X-Ray or } \\
\text { Catscan and come back to the room }\end{array}$ & 13.4 minutes \\
\hline
\end{tabular}

Table VII shows the average time for value added doctor steps. Doctors spent an average time of 32.5 minutes in the patient's room, with $57.5 \%$ of the 32.5 minutes being the visits by the doctor after the doctor's first visit. The average number of time a doctor visits a patient is 3.8 times

TABLE VII

VALUE ADDED TIME: DOCTOR STEPS

\begin{tabular}{|l|c|}
\hline $\begin{array}{l}\text { Average time a Doctor spends in the room during the } \\
\text { Doctor's } 1^{\text {st }} \text { visit }\end{array}$ & 13.8 minutes \\
\hline $\begin{array}{l}\text { Average time a Doctor spends in the room after the } \\
\text { Doctor's } 1^{\text {st }} \text { visit }\end{array}$ & 18.7 minutes \\
\hline Average number of times a Doctor comes into a room & 3.8 times \\
\hline Average total time a Doctor spends in a room & 32.5 minutes \\
\hline
\end{tabular}

Even though value added time can be decreased, decreasing the non-value added time will have the biggest impact on the overall ER visit time. By finding solutions to these events and conflicts, the high percentage of non-value added time will decrease. 
The non-value added time events and conflicts are listed in the next chapter with the recommendations to eliminate this time. 


\section{RECOMMENATIONS}

The recommendation chapter first addresses the ways to decrease critical step time. Then, the second part of the chapter reports on the non-value added time events and conflicts. Solutions are also listed for each non-value added time event and conflict.

The critical steps of the PCA taking the patient to X-Ray/Catscan and bringing the patient back to the emergency room have the longest time of the critical nurse steps, with an average time of 13.4 minutes. This time includes the time the technologist is taking the X-Ray/Catscan, which is less than half of the 13.4 minutes. The majority of the 13.4 minutes is spent waiting for the PCA to return to the $\mathrm{X}$-Ray/Catscan area to take the patient back to the emergency room. Two solutions to this problem are to either have the technologist take the patient back to the emergency room or hire more PCAs for this patient transport. Solving this problem can help patients get through X-Ray/Catscan faster, which will allow the doctor to evaluate the patient's results sooner.

Some of the doctor's visits were reassuring the patient that the results of tests will be known soon or the doctor would go into the room and then realize another piece of equipment was needed and would have to go get that equipment. A possible solution to decrease this time is to have the nurse let the patient know that results will be known soon or the nurse going to get the equipment for the doctor.

Non-value added time is $66 \%$ of the total patient throughput time, decreasing this time is needed to improve throughput time. Non-value added time includes any time spent on non-critical activities such as waiting time and events or conflicts that happen 
while the patient is between critical steps. Table VIII shows the non-value added time:

events and Table IX shows the non-value added time: conflicts.

\section{TABLE VIII}

NON-VALUE ADDED TIME: EVENTS

\begin{tabular}{|l|l|}
\hline Problem & Solution \\
\hline $\begin{array}{l}\text { PCAs cannot find a wheelchair to transport } \\
\text { patient to get an X-Ray or Catscan }\end{array}$ & $\begin{array}{l}\text { Have wheelchairs assigned to each hallway } \\
\text { and do not take wheelchairs from other } \\
\text { hallways or departments }\end{array}$ \\
\hline $\begin{array}{l}\text { In between shifts, it takes a long time for } \\
\text { nurses to transition: personal time }\end{array}$ & $\begin{array}{l}\text { Have a set list of questions that the } \\
\text { outgoing nurse needs to answer about the } \\
\text { patients assigned to them and just give it to } \\
\text { the incoming nurse on a sheet of paper }\end{array}$ \\
\hline $\begin{array}{l}\text { PCA is not available to take patient to } \\
\text { Catscan/X-Ray and to pick them up }\end{array}$ & $\begin{array}{l}\text { The PCA should stay in the hallway they } \\
\text { are assigned to and have a floater PCA that } \\
\text { stays by the main desk }\end{array}$ \\
\hline $\begin{array}{l}\text { Patient liaison takes patient to wrong } \\
\text { location for Catscan }\end{array}$ & $\begin{array}{l}\text { PCA/Nurse should only take patient to } \\
\text { Catscan and they should go to waiting area } \\
\text { for Catscan and not X-Ray }\end{array}$ \\
\hline $\begin{array}{l}\text { For patients who need breathing } \\
\text { treatments, they should be started as soon } \\
\text { as possible }\end{array}$ & $\begin{array}{l}\text { Have more respiratory technologists during } \\
\text { asthma peak seasons and have PCA check } \\
\text { on how their breathing treatments are going } \\
\text { to help out respiratory technologist }\end{array}$ \\
\hline The IV team is overloaded & $\begin{array}{l}\text { Have more PCAs to help the nurse out, } \\
\text { analysis of having more IV teams in Kosair } \\
\text { and training nurses to practice putting IVs } \\
\text { in during difficult situations }\end{array}$ \\
\hline $\begin{array}{l}\text { PCAs have to search for machines to check } \\
\text { vitals }\end{array}$ & $\begin{array}{l}\text { Each PCA should be assigned one for their } \\
\text { shift and they should not be taken from } \\
\text { other hallways and especially never take } \\
\text { the ones from the trauma room }\end{array}$ \\
\hline
\end{tabular}


TABLE IX

NON-VALUE ADDED TIME: CONFLICTS

\begin{tabular}{|l|l|}
\hline Problem & Solution \\
\hline $\begin{array}{l}\text { When rooms are filled, sometimes patients } \\
\text { will go in a hallway's procedure room (for } \\
\text { hallway A, it is room 5), this makes } \\
\text { patients who need procedures have to wait } \\
\text { a lot longer }\end{array}$ & $\begin{array}{l}\text { if a patient comes from an ambulance and } \\
\text { them go to the waiting room }\end{array}$ \\
\hline Patient liaison takes away nurses time & $\begin{array}{l}\text { Patient liaisons should be educated in } \\
\text { common questions that patients will ask: } \\
\text { such as how long it takes for a doctor to } \\
\text { read a Catscan/X-Ray and standard } \\
\text { procedures }\end{array}$ \\
\hline $\begin{array}{l}\text { The charge nurse is overloaded and does } \\
\text { not have time to answer questions from } \\
\text { doctors and nurses, patients need to be } \\
\text { admitted }\end{array}$ & Have a floater nurse help out \\
\hline
\end{tabular}

Short patient throughput time added together with high quality of care equals high patient satisfaction. Putting the solutions from the problems found in the time study into action will make patient throughput time shorter, and therefore increasing patient satisfaction. 


\section{CONCLUSIONS AND FUTURE RESEARCH}

Patient satisfaction will be improved in the emergency room at Kosair Children's Hospital by implementing the solutions to the problems found in the time study. However, in order to continue to have high patient satisfaction ratings after the implementation, continuous improvement is critical. Future studies that will improve the emergency room include: simulation of the emergency room, analysis of nurse/resident to patient assignments, analysis of time before the doctor comes into the room, analysis of IV team, analysis of ancillary services, and cost analysis of additional resources.

Simulation of the emergency room will allow the hospital to view different changes before implementation to see how the changes will affect the emergency room. Areas that could be improved by the simulation include, but are not limited to: emergency room layout, the number of staff for a shift/particular season and, utilization of critical steps. DeGennaro et al. (2004) reported using a simulation to find out if cross training nurses to perform ancillary services would improve patient throughput time in that particular emergency room. A simulation will allow hospitals to test possible changes before implementation.

Analysis of nurse to patient assignments is another area that should be investigated further. The current nurse allocation plan of two RNs and one PCA per hallway should be analyzed to see if that is the most efficient assignment. Another area that needs to be analyzed is the effect that new residents to the ER have on the patient throughput time. The time study was done when the residents first started their rotation 
in the ER. Another time study should be done when they are ending their rotation in the ER.

Before the doctor's first visit to the patient's room, the patient can be waiting in the room for approximately 90 minutes. This time study did not consider the time before the doctor's first visit. A new time study should be done analyzing the time of the patient waiting in the room before the doctor's initial visit.

Adding another IV team and training nurses on inserting an IV in a patient during a difficult situation should be analyzed to see how much patient throughput time is improved. Presently, waiting on the IV team is a bottleneck that needs to be improved for higher patient satisfaction.

The time study analyzed the time while the ancillary services took place. However, a new time study on just ancillary services is needed. The patient returns to the emergency room in a short time; however, it took at least 60 minutes after the patient got back to the room for test results to be given. Since waiting for test results is a bottleneck, this process needs to be further studied.

The analysis of this time study suggests the possible hiring of additional employees to improve patient throughput time. It is important to evaluate the benefit of additional employees using a simulation. Then a cost analysis can be conducted to determine if the benefits of additional employees exceed the costs. 


\section{REFERENCES}

Burdick, T., Cochran J., Kisiel S., \& Modena C. (2007). Banner Health/Arizona State University Partnership in Redesigning Emergency Department Care Delivery focusing on Patient Safety. 19th Annual IIE Society for Health Systems Conference.

DeGennaro, M., Gandhi, T., Kushner, L., Nagarkar, K., Rivero, R., \& Srihari, K. (2004). Effective Utilization of Ancillary Services to reduce Patient Turnaround Times at an Emergency Room. IIE Annual Conference and Exhibition, 2093-2104.

Gonzalez, C., Gonzalez, M., \& Rios, N. (1997). Improving the Quality of Service in an Emergency Room using Simulation-Animation and Total Quality Management. Computers and Industrial Engineering, 33(1-2), 97-100.

Johnson, C., Roberts, L., Shanmugam, R., \& Zinkgraf, S. (2004). Linking Lean Healthcare to Six Sigma: An Emergency Department Case Study. IIE Annual Conference and Exhibition.

Kosair Children's Hospital. (2010). Ground Floor. Retrieved November 24, 2009, from http://www.nortonhealthcare.com/workfiles/KCH/KCH_AllFloors_Ground.pdf

Lin, L., \& Paul, J. (2007). Simulation and Parametric Models for Improving Patient Throughput in Hospitals. $19^{\text {th }}$ Annual Society for Health Systems Conference.

Malakooti, N. (2004). Emergency Room Design based on Production, Process Planning, and Cell Formation. IIE Annual Conference and Exhibition 2004, 1363-1367.

National Center for Health Statistics (2009). Health, United States, 2008. U.S. Government Printing Office. Retrieved from http://www.cdc.gov/nchs/data/hus/hus08.pdf.

PPRU. (2010). University of Louisville/Kosair Children's Hospital. Retrieved October 19, 2009, from http://www.ppru.org/louisville.html 


\section{APPENDIX I}

TABLE X

INDIVIDUAL PATIENT WAIT TIME (IN MINUTES)

\begin{tabular}{|l|l|l|l|}
\hline Patient & $\begin{array}{l}\text { Severity } \\
\text { Level }\end{array}$ & Condition & $\begin{array}{l}\text { Wait } \\
\text { Time } \\
\text { in } \\
\text { Room }\end{array}$ \\
\hline 1 & Yellow & Head injury & 142 \\
\hline 2 & Orange & Head trauma & 63 \\
\hline 3 & Yellow & Leg pain & 74 \\
\hline 4 & Yellow & Fall & 116 \\
\hline 5 & Yellow & Fall & 132 \\
\hline 6 & Yellow & Seizure & 151 \\
\hline 7 & Yellow & Head LAC & 129 \\
\hline 8 & Yellow & Arm injury & 110 \\
\hline 9 & Yellow & $\begin{array}{l}\text { Difficulty } \\
\text { breathing }\end{array}$ & 23 \\
\hline 10 & Orange & Asthma & 86 \\
\hline & & Average $=$ & 102.60 \\
\hline & & $\begin{array}{l}\text { Standard } \\
\text { deviation }=\end{array}$ & 40.40 \\
\hline
\end{tabular}


TABLE XI

INDIVIDUAL PATIENT TIME WITH DOCTOR (IN MINUTES)

\begin{tabular}{|r|l|l|r|r|r|r|}
\hline & Severity & Condition & $\begin{array}{l}\text { Dr.'s } \\
\mathbf{1}^{\text {st }} \\
\text { visit }\end{array}$ & $\begin{array}{l}\text { Dr. } \\
\text { Time } \\
\text { after 1 } \\
\text { visit }\end{array}$ & $\begin{array}{l}\text { st } \\
\text { Number } \\
\text { of Dr. } \\
\text { visits }\end{array}$ & $\begin{array}{l}\text { Total } \\
\text { Dr. } \\
\text { Time }\end{array}$ \\
\hline 1 & Yellow & Head injury & 23 & 10 & 3 & 33 \\
\hline 2 & Orange & Head trauma & 18 & 76 & 4 & 94 \\
\hline 3 & Yellow & Leg pain & 14 & 20 & 3 & 34 \\
\hline 4 & Yellow & Fall & 8 & 5 & 2 & 13 \\
\hline 5 & Yellow & Fall & 3 & 15 & 5 & 18 \\
\hline 6 & Yellow & Seizure & 8 & 4 & 18 \\
\hline 7 & Yellow & Head LAC & 14 & 31 & 7 & 12 \\
\hline 8 & Yellow & Arm injury & 23 & 7 & 4 & 30 \\
\hline 9 & Yellow & Difficulty breathing & 16 & 12 & 3 & 28 \\
\hline 10 & Orange & Asthma & 13.80 & 18.70 & 3.80 & 32.50 \\
\hline & & Average $=$ & 6.49 & 21.75 & 1.40 & 24.01 \\
\hline & & Standard deviation & & & & \\
\hline
\end{tabular}


TABLE XII

INDIVIDUAL PATIENT TIME WITH NURSE (IN MINUTES)

\begin{tabular}{|r|l|l|r|r|r|r|}
\hline & Severity & Condition & $\begin{array}{l}\text { Number of } \\
\text { Nurse Visits }\end{array}$ & $\begin{array}{l}\text { Total Nurse } \\
\text { Time }\end{array}$ & $\begin{array}{l}\text { Number } \\
\text { of PCA } \\
\text { visits }\end{array}$ & $\begin{array}{l}\text { Total } \\
\text { PCA } \\
\text { Time }\end{array}$ \\
\hline 1 & Yellow & Head injury & 1 & 2 & 2 & 4 \\
\hline 2 & Orange & Head trauma & 2 & 5 & 1 & 3 \\
\hline 3 & Yellow & Leg pain & 1 & 1 & 0 & 0 \\
\hline 4 & Yellow & Fall & 2 & 4 & 0 & 0 \\
\hline 5 & Yellow & Fall & 3 & 3 & 1 & 7 \\
\hline 6 & Yellow & Seizure & 3 & 16 & 3 & 16 \\
\hline 7 & Yellow & Head LAC & 2 & 4 & 2 & 5 \\
\hline 8 & Yellow & Arm injury & 2 & 5 & 1 & 3 \\
\hline 9 & Yellow & Difficulty breathing & 1 & 3 & 0 & 0 \\
\hline 10 & Orange & Asthma & 2 & 5 & 4 & 17 \\
\hline & & Average & 1.90 & 4.80 & 1.40 & 5.50 \\
\hline & & Standard deviation & & & & \\
& & & 0.74 & 4.16 & 1.35 & 6.24 \\
\hline
\end{tabular}


TABLE XIII

INDIVIDUAL PATIENT TIME IN ANCILLARY SERVICES

\begin{tabular}{|c|c|c|c|c|c|c|}
\hline Patient & $\begin{array}{l}\text { Severity } \\
\text { Level }\end{array}$ & Condition & $\begin{array}{l}\text { Resp. } \\
\text { visit }\end{array}$ & Catscan & $\begin{array}{l}\text { X- } \\
\text { Ray }\end{array}$ & $\begin{array}{l}\text { Patient is in } \\
\text { Procedure } \\
\text { Room }\end{array}$ \\
\hline 1 & Yellow & Head injury & & 7 & 0 & 0 \\
\hline 2 & Orange & Head trauma & & 7 & 0 & 0 \\
\hline 3 & Yellow & Leg pain & & 15 & 0 & 0 \\
\hline 4 & Yellow & Fall & & 6 & 0 & 0 \\
\hline 5 & Yellow & Fall & & 0 & 32 & 0 \\
\hline 6 & Yellow & Seizure & & 0 & 0 & 0 \\
\hline 7 & Yellow & Head LAC & & 0 & 0 & 20 \\
\hline 8 & Yellow & Arm injury & & 0 & 0 & 0 \\
\hline 9 & Yellow & Difficulty breathing & & 0 & 0 & 0 \\
\hline \multirow[t]{3}{*}{10} & Orange & Asthma & & 0 & 0 & 0 \\
\hline & & Average $=$ & 0.1 & 3.50 & 3.20 & 2.00 \\
\hline & & $\begin{array}{l}\text { Standard deviation } \\
=\end{array}$ & 0.3 & 5.13 & 10.12 & 6.32 \\
\hline
\end{tabular}

TABLE XIV

INDIVIDUAL PATIENT TOTAL THROUGHPUT TIME

\begin{tabular}{|c|c|c|c|}
\hline Patient & Severity Level & Condition & $\begin{array}{l}\text { Total } \\
\text { Time }\end{array}$ \\
\hline 1 & Yellow & Head injury & 190 \\
\hline 2 & Orange & Head trauma & 171 \\
\hline 3 & Yellow & Leg pain & 126 \\
\hline 4 & Yellow & Fall & 141 \\
\hline 5 & Yellow & Fall & 194 \\
\hline 6 & Yellow & Seizure & 190 \\
\hline 7 & Yellow & Head LAC & 171 \\
\hline 8 & Yellow & Arm injury & 165 \\
\hline 9 & Yellow & Difficulty breathing & 58 \\
\hline \multirow[t]{3}{*}{10} & Orange & Asthma & 139 \\
\hline & & Average $=$ & 154.50 \\
\hline & & Standard deviation = & 41.21 \\
\hline
\end{tabular}




\section{APPENDIX II}

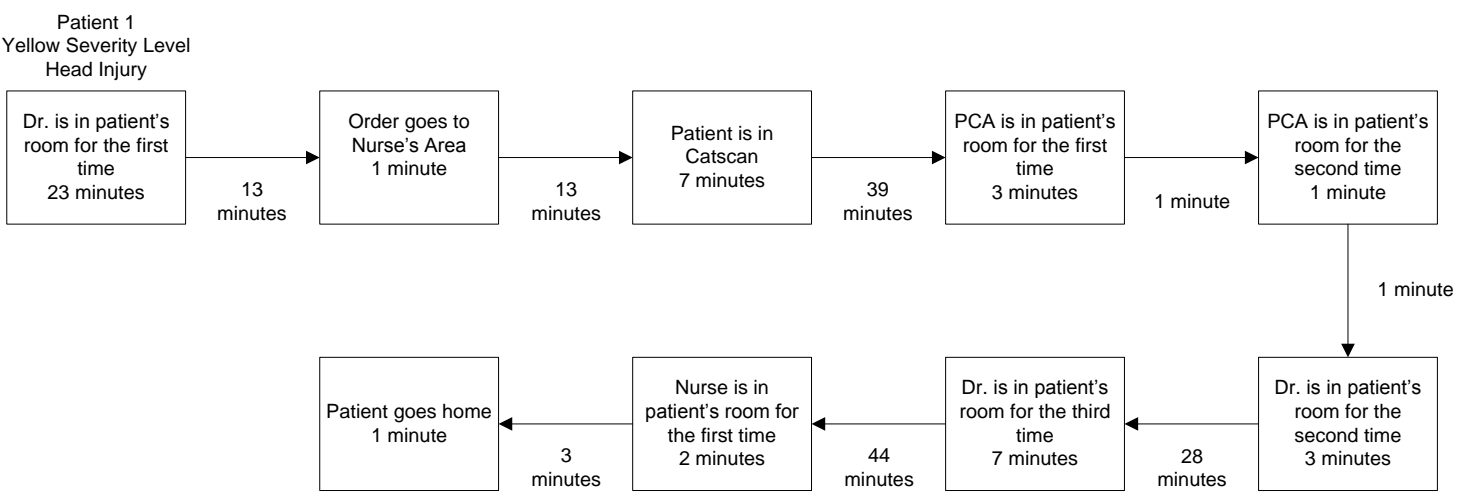

FIGURE 3 - Process Flow for Patient \# 1

Patient 2

Orange Severity Level

Head Trauma

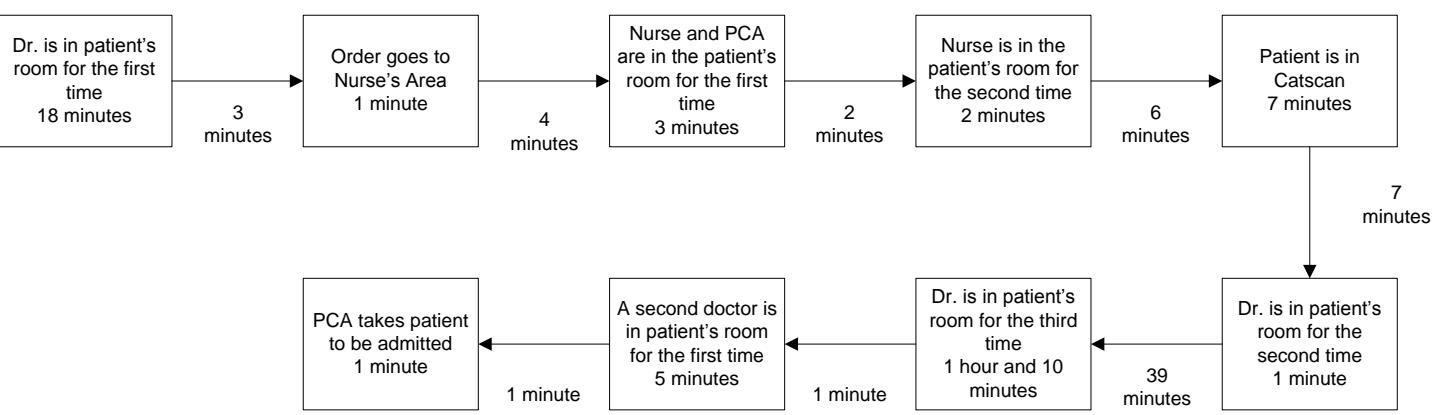

FIGURE 4 - Process Flow for Patient \# 2 
Patient 3

Yellow Severity Level

Dr. is in patient's room for the first
rom room for the
time

$\longrightarrow$\begin{tabular}{|l|l|}
$\begin{array}{c}\text { Dr. is in patient's } \\
\text { room for the } \\
\text { second time } \\
1 \text { minute }\end{array}$ & $\begin{array}{c}13 \\
\text { minutes }\end{array}$
\end{tabular}

\begin{tabular}{|l|}
\hline Order goes to \\
Nurse's Area \\
1 minute
\end{tabular}

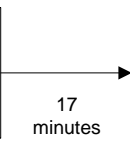

\begin{tabular}{|c|} 
Patient is in \\
Catscan \\
15 minutes
\end{tabular}

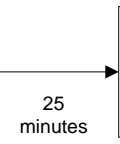

Dr. is in patient's room for the third

1 minute
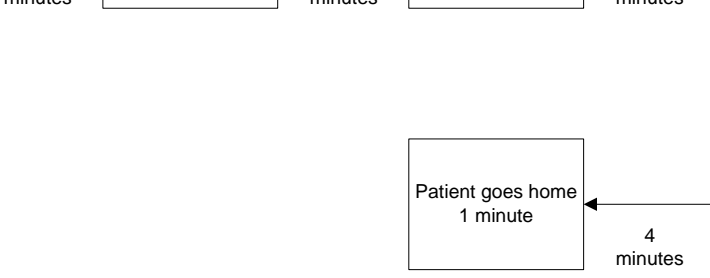

19 minutes

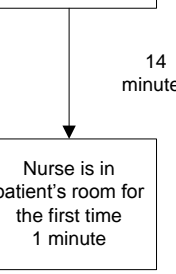

FIGURE 5 - Process Flow for Patient \# 3

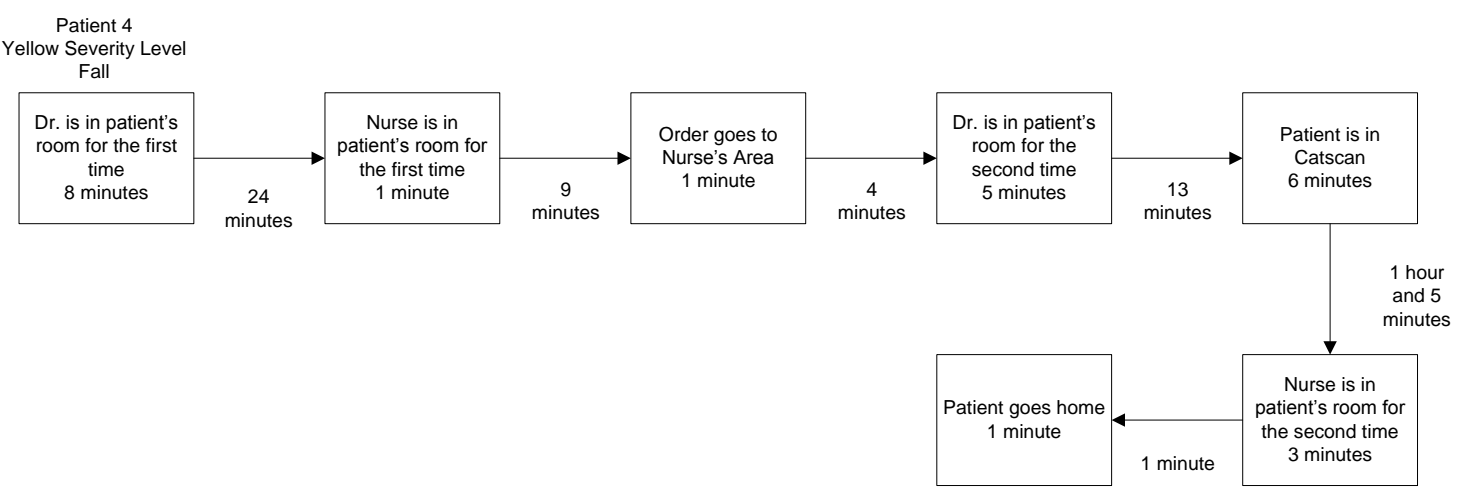

FIGURE 6 - Process Flow for Patient \# 4 


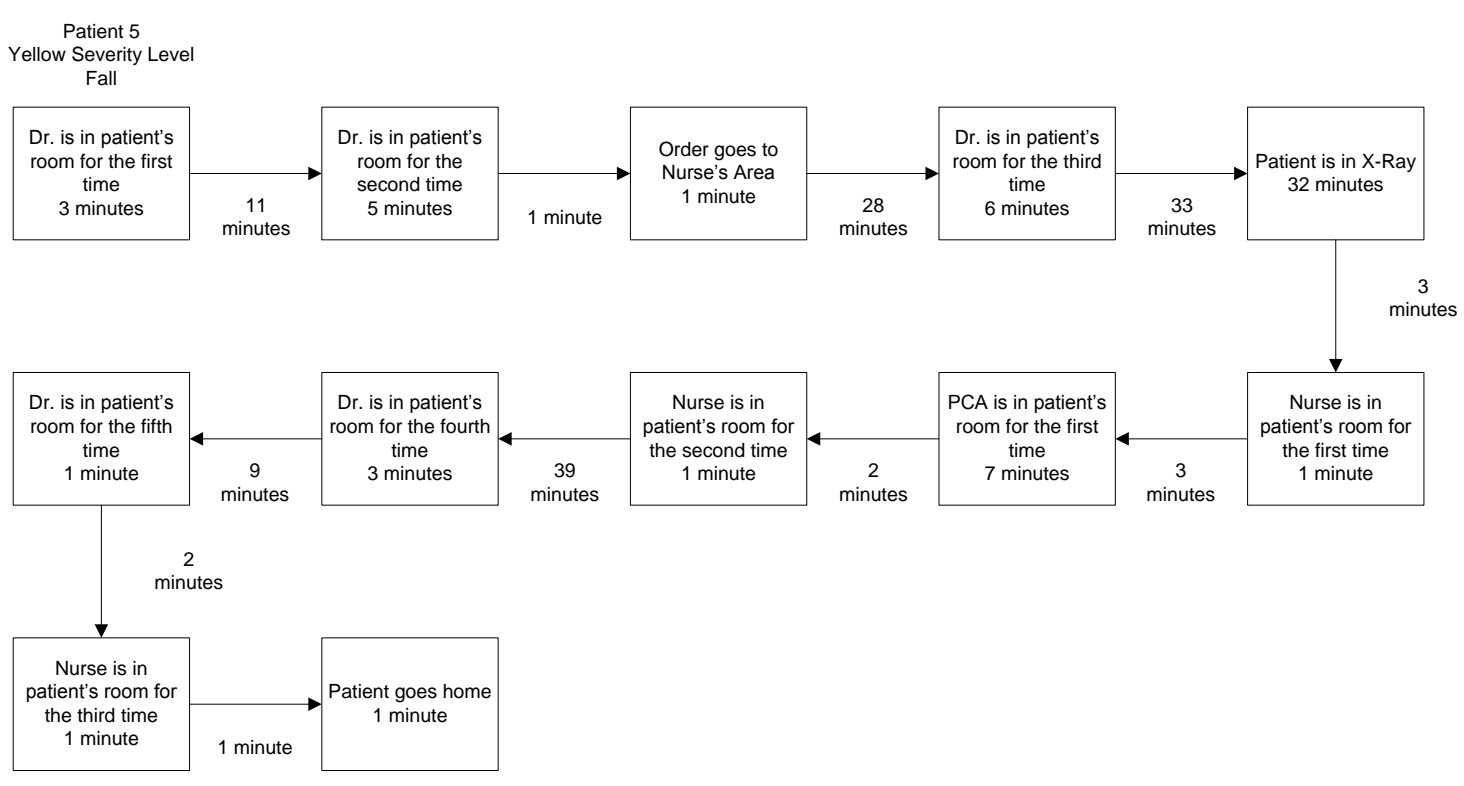

FIGURE 7 - Process Flow for Patient \# 5

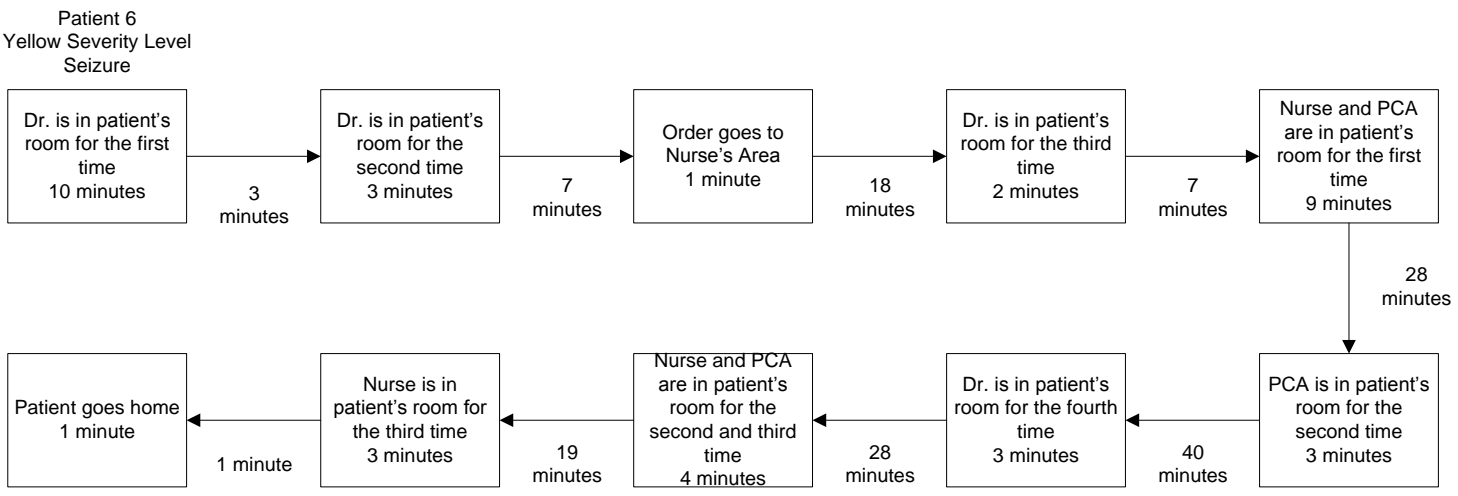

FIGURE 8 - Process Flow for Patient \# 6 
Patient 7

Yellow Severity Level

Head LAC

Dr. is in patient's

room for the first

time

9 minutes

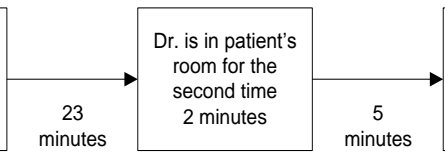

\begin{tabular}{|c|c|}
$\begin{array}{c}\text { Nurse is in } \\
\text { patient's room for } \\
\text { the first time } \\
3 \text { minutes }\end{array}$ & \\
& 25 \\
& \\
minutes
\end{tabular}

PCA is in patient's room for the first

time

4 minutes
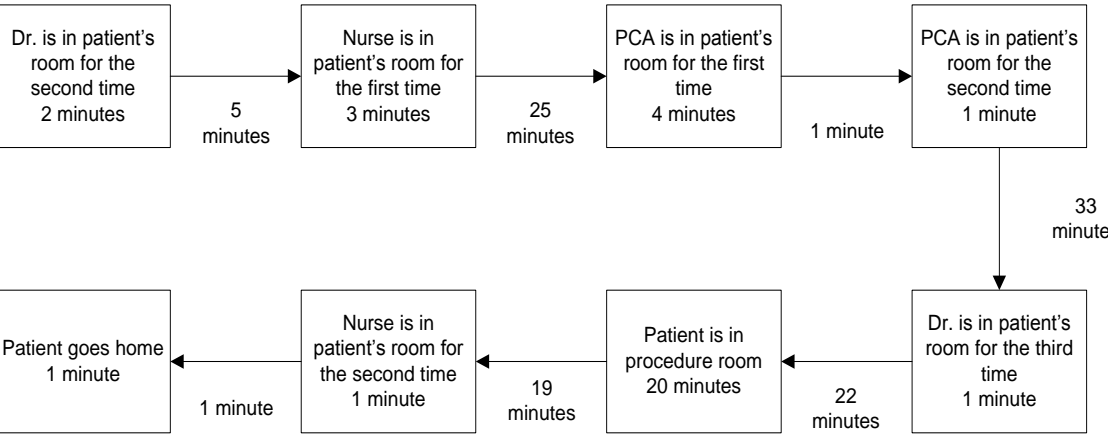

FIGURE 9 - Process Flow for Patient \# 7

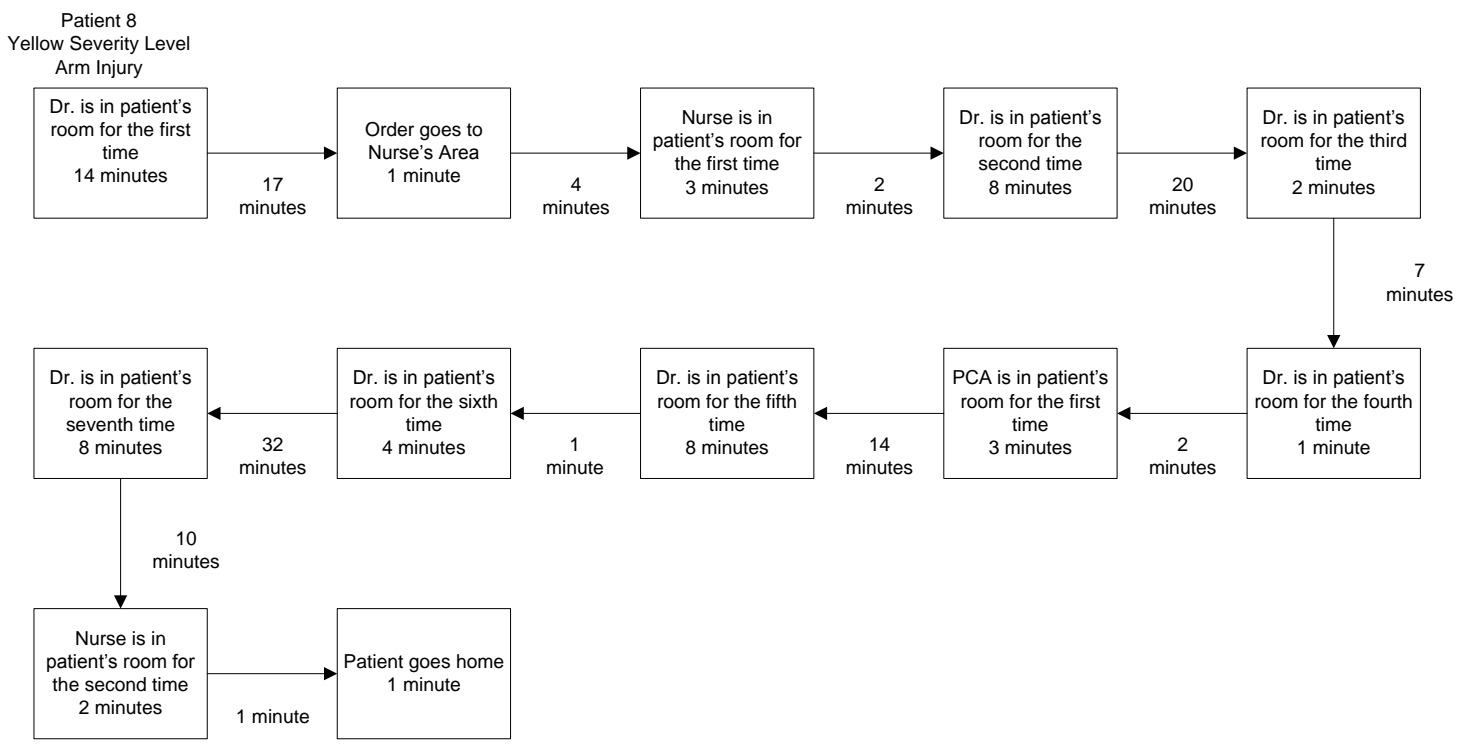

FIGURE 10 - Process Flow for Patient \# 8 
Patient 9

Yellow Severity Level

Difficulty Breathing

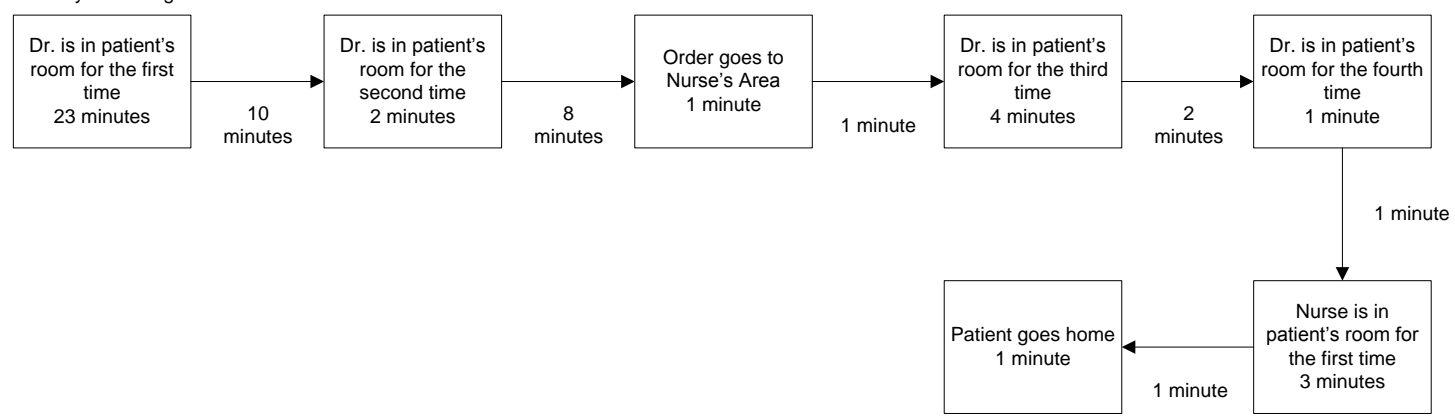

FIGURE 11 - Process Flow for Patient \# 9

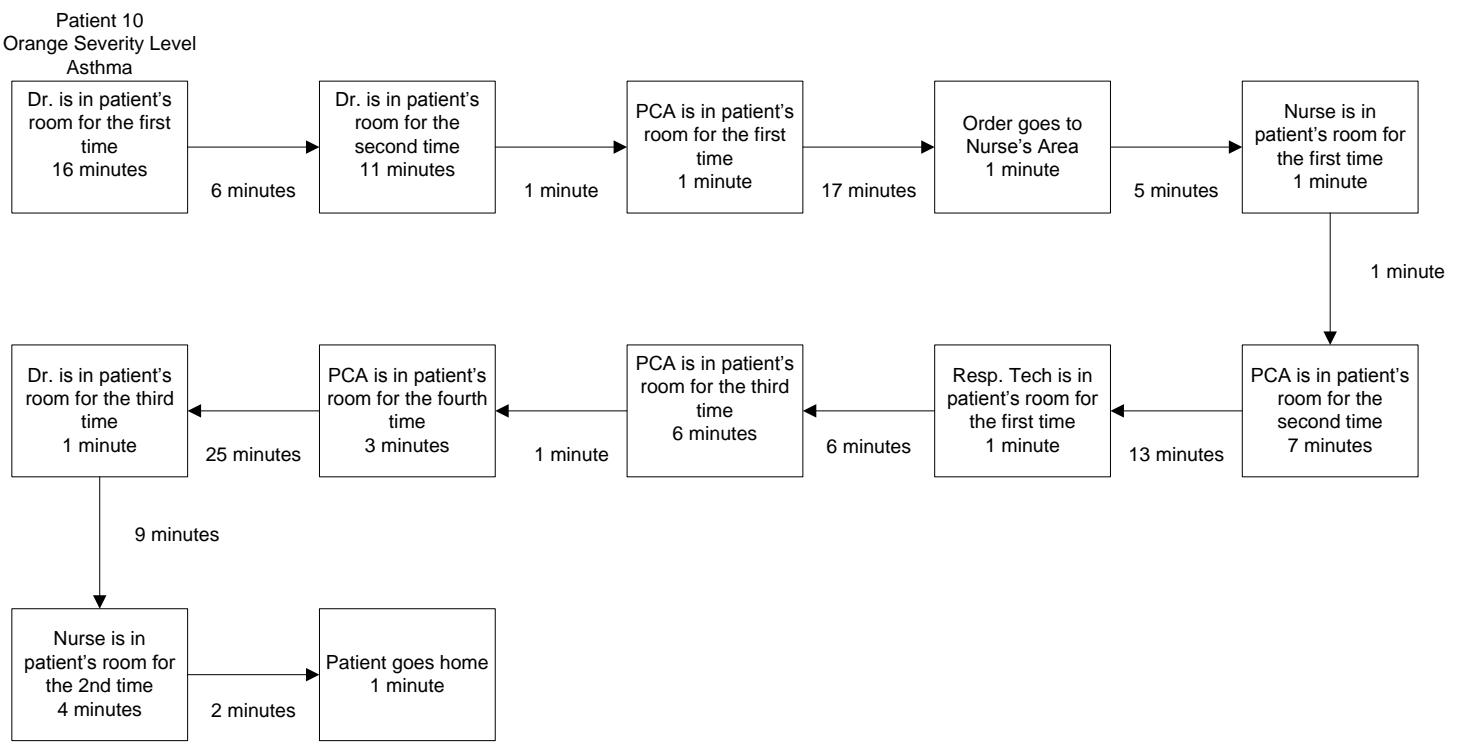

FIGURE 12 - Process Flow for Patient \# 10 


\section{ELIZABETH GENTRY}

6002 Table Mountain Avenue

Louisville, KY 40214

louisvilleliz@gmail.com

\section{EDUCATION}

Aug 2009-present

University of Louisville, J.B. Speed School of Engineering

Louisville, KY

Doctorate in Engineering/Industrial Engineering

Graduation: May 2012

Aug 2008-Dec 2009

University of Louisville, J.B. Speed School of Engineering

Louisville, KY

Masters in Engineering/Industrial Engineering

Graduation: December 2009

Jan 2005-Aug 2008

University of Louisville, J.B. Speed School of Engineering

Louisville, KY

Bachelor of Science in Industrial Engineering

Graduation: August 2008

ACTIVITIES \& HONORS

- Sigma Kappa Sorority Alumna Executive Council

- Tutor for University of Louisville Athletics

- Industrial Engineering Graduate Research Assistant

- University of Louisville Greek Sing Co-Chair for 2009

- Human Factors and Ergonomics Society

- WHAS Crusade for Children

- Institute of Industrial Engineers

- Rho Lambda Honor Society

- Society of Women Engineers 